\title{
Easy Diagnosis of Basal Cell Carcinoma by Demosocpie
}

\section{Assenhaji I*, Bennani M, Ziani J, Douhi Z, Elloudi S, Baybay H and Mernissi FZ \\ Departement of Dermatology, Hassan II Hospital University, Fez, Morocco}

*Corresponding author: Assenhaji louizi ibtissam, Centre hospitalier, hrazem, BP: 1835 Atlas, Fès, Avenue hassan II, Fès30050, Morocco; Email: assenhaji.louizi@outlook.fr

\section{Case Report}

Volume 5 Issue 1

Received Date: February 11, 2020

Published Date: February 28, 2020

DOI: $10.23880 /$ cdoaj-16000205

\section{Abstract}

The BCC is a cancer with low grade and rares métastases. Superficial basal cell carcinoma (SSBCC) comprise up to $25 \%$ of all histological sub-types. They are more likely to occur on the trunk and in the younger age groups especially in females. SSBCC appears as a scaly and well-defined area. It can resemble a patch of dermatitis and can be confused with eczema, psoriasis, lichen planus, or Bowen's disease. Thus, the clinical features alone may not point to the appropriate diagnosis. The histopathology is the most reliable diagnostic modality for SSBCC. Surgical excision is the most commonly used treatment for BCC. Topical chemotherapy agents such as imiquimod or 5-fluorouracil may be various alternatives or adjuvants in the treatment of SSBCC.

Keywords: Superficial basal cell carcinoma; Clinical; Dermoscopy

\section{Case Report}

It is a patient of 53 years, without significant pathological antecedents, who presents for 2 years a lesion in the right hypochondrium, gradually increasing in size. Clinical examination found a slightly infiltrated $2 \mathrm{~cm}$ plaque with a pearled outline at the level of the right hypochondrium (Figure 1), dermoscopy showing ovoid nests, dots and globules, eccentric radial striations, and a maple leaf appearance (Figure 2).

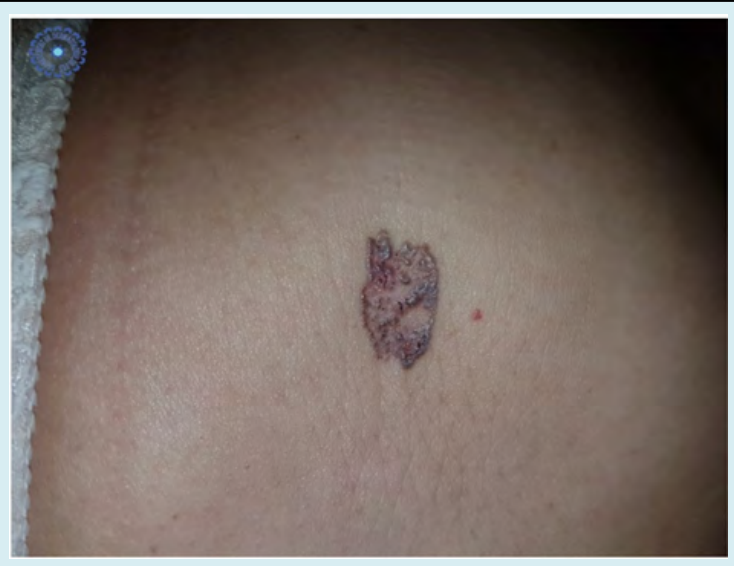

Figure 1: Infiltrated $2 \mathrm{~cm}$ plaque with a pearled outline at the level of the right hypochondrium.

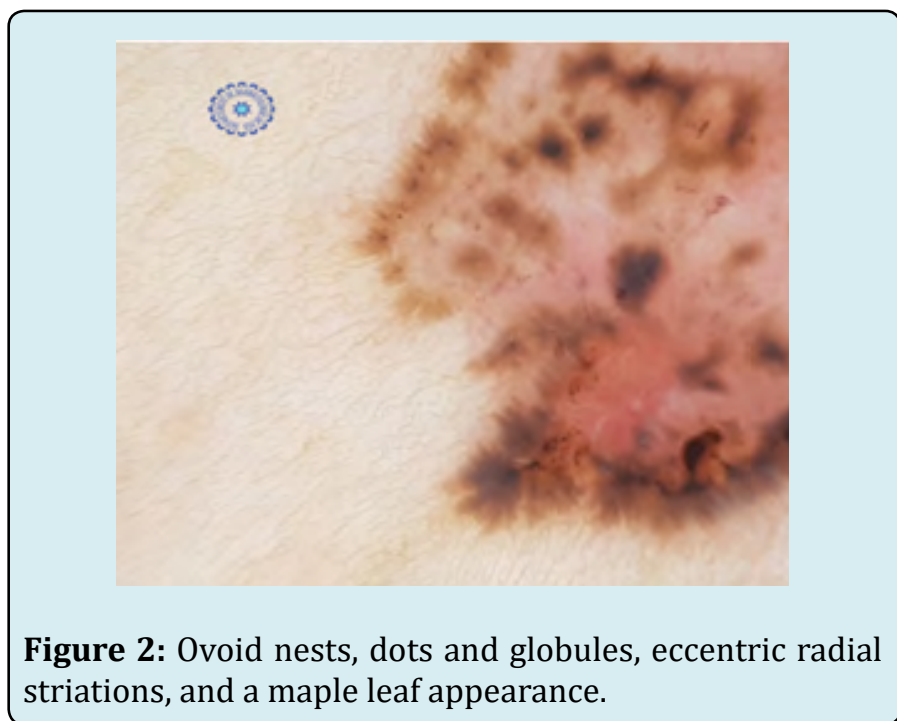

The histopathology exam was in favor of a superficial basal cell carcinoma, with healthy margins, and the evolution was favorable without recurrence.

\section{References}

1. Singha J, Patel N (2016) Superficial Basal Cell Carcinoma on the Face is a Diagnostic Challenge Indian J Dermatol 
61(2): 236.

2. Wong CSM, Strange RC, Lear JT (2003) Basal cell carcinoma. BMJ 327(7418): 794-798.

3. Bastiens MT, Hoefnagel JJ, Bruin JA, Westendorp RG, Vermeer BJ, et al. (1998) Differences in age, site distribution and sex between nodular and superficial basal cell carcinomas indicate different types of tumours. Jnl Invest Dermatol 110(6): 880-884.
4. Chen CC, Chen CL (2006) Clinical and histopathologic findings of superficial basal cell carcinoma: A comparison with other basal cell carcinoma subtypes. J Chin Med Assoc 69(8): 364-371.

5. Scalvenzi M, Lembo S, Francia MG, Balato A (2008) Dermoscopic patterns of superficial basal cell carcinoma. Int J Dermatol 47(10): 1015-1018. 